\title{
Imaginary and Pretos Velhos - Adaptation of a Brazilian Symbol in European Contexts
}

\author{
Pauline Monteiro (iD https://orcid.org/0000-0002-8205-7216 \\ Centre d'études en Sciences Sociales du Religieux (CéSor) \\ Ecole des Hautes Etudes en Sciences Sociales \\ paulinemonteiro@hotmail.fr
}

\begin{abstract}
This article seeks to show, through an examination of music and Pretos Velhos ${ }^{1}$ entities, the transnationalization and the adaptation of an Afro-Brazilian cult of possession (Umbanda) in a French, Belgian and Swiss contexts. By analysing songs, dances and rhythms, I focus on the diacritical characteristics from Pretos Velhos entities in Umbanda and on the discourses of mediums (during and after possession), to emphasize the representation of these entities in their adaptation society. The purpose of this article is to show how the Pretos Velhos, and also music (rhythms and dances), are one strategic point of adaptation of Afro-Brazilian cults. The work of imagination (here conveyed by music), shows the transcendence of a historical symbol by a European romantic symbol (the storyteller) that will create this new area where the Umbanda can adapt to the European contexts.
\end{abstract}

Keywords: Pretos Velhos, Umbanda, transnationalization, music, imagination, Europe

Słowa kluczowe: Pretos Velhos, Umbanda, transnacjonalizacja, muzyka, wyobraźnia, Europa

For this study, I worked with Temple Guaracy in France (Paris), Belgium (Brussels) and Switzerland (Geneva) from 2014 to 2017. Temple Guaracy was the subject of Viola Teisenhoffer's thesis, in which she focuses on the New Age aspect of this Umbanda temple. ${ }^{2}$ For my case, I concentrate only on the music and the relationship between symbols which are carried in lyrics, rhythms, dances and the appropriation of them by European mediums.

${ }_{1}$ The Pretos Velhos are a representation of old blacks slaves. I will develop further on the specificities related to these entities.

${ }^{2}$ An important point of the transnationalization of Umbanda, I will come back to this later in the article. 
Argyriadis, ${ }^{3}$ Rossbach de Olmos, ${ }^{4}$ Bahia,${ }^{5}$ and Bahia and Vieira ${ }^{6}$ have already stressed the importance of music in the transnationalization of the Orisha religion in Europe. Indeed, music (as well as travel and mixed marriages) has allowed Europeans to come into contact with the religion. However, I would like to go a little further by showing that music also helps to re-appropriate symbols that are deeply rooted in Brazilian society. It becomes a "trading zone" where language (the speeches of entities) makes it possible to grasp (at least to touch) this work of imagination.

In this article I would like to study the cardinal aspects of music (lyrics, dance and rhythms) in the transnationalization of Umbanda in Europe: the transmission of social stereotypes and the performance of the Brazilian imaginary beyond the borders through songs dedicated to Pretos Velhos. Indeed, in the possession cults, the music structures the ritual and the songs are mytho-poems telling the histories of the entities. In Brazil, the image of the Preto Velho is not only that of a religious figure, it is also a "character" already present in the "dominant" culture with a concomitant evolution towards various representations of the "Black" according to socio-historical periods. This representation of slavery has the quality of highlighting social discussions: nationalism, and the relationships among race, slavery and national identity. However, once integrated in Swiss, Belgian or French cults, Preto Velho conjures an imaginary closer to a European imaginary about old people (like that of the old storyteller) than national debates.

Thus, through the songs, rhythms and dances related to these sounds, I would like to emphasize the idea, the speeches and therefore the imaginary summoned in Switzerland, Belgium and in France as regards the Pretos Velhos.

\section{Origin of a Brazilian entity}

The Preto Velho (literally "old black man") is a common entity in Umbanda, the Afro-Brazilian possession cult which arose around 1920 in Rio de Janeiro. ${ }^{8}$ Umbanda was borne from encounters among Kardecism, popular Catholicism, Amerindian religious practices and Afro-Brazilian religions. The cult is based on the Yoruba

\footnotetext{
${ }^{3} \mathrm{~K}$. Argyriadis, Les parisiens et la santería - de l'attraction esthétique à l'implication religieuse, "Psychopathologie africaine" 2002, vol. 31, no. 1, pp. 17-44.

${ }^{4}$ L. Rossbach de Olmos, Santeria Abroad. The Short History of an Afro-Cuban Religion in Germany by Means of Biographies of Some of Its Priests, “Anthropos" 2009, vol. 104, pp. 483-497.

5 J. Bahia, Religiosidad afro-brasileño en Berlín: adaptaciones en la transnacionalización del candomblé, "Sociedad y discurso" 2005, no. 28(7), pp. 7-25.

${ }^{6}$ J. Bahia, C. Vieira, Performances artísticas e circularidades das simbologias afro religiosas, "Revista brasileira de História das Religiões" 2017, vol. 9, no. 17, pp. 171-188.

${ }^{7}$ See P. Galison, Image and Logic. A Material Culture of Microphysics, Chicago1997, p. 982. The "trading zone" is a metaphor to explain how two (or more) groups can agree upon rules of exchange even if they give different interpretations to the exchanged objects. They develop a local coordination despite the global difference (for exemple, Pidgin).

${ }^{8}$ See L.N. Negrão, Umbanda: entre a cruz e a encruzilhada, "Tempo Social" 1993, vol. 5 no. 1-2, pp. 113-122.
} 
pantheon, as Candomblé and other cults come from the religion of Orisha. The African gods lead the "phalanxes" and "lines" of work. Thus, in the Yemanjá line, entities such as Pretos Velhos "work." In this pantheon, entities are ranked according to whether they are "spirits of light" (such as caboclos, Amerindians) or "spirits of darkness" (such as Exu).

In the 1930s, the white intellectual elites who practiced the cult sought to make it a national religion linked to racial democracy, thus claiming an "ideal of reconciliation." Nevertheless, the history of this entity is inextricable from the representation of the "Black" in Brazil. Indeed, the Preto Velho is a typical figure whose origin can be traced back to the first abolitionist writings of the eighteenth century by the Jesuit António Vieira (1608-1697) and the Portuguese poet Gregório de Matos Guerra. However, the expansion of the Black in Brazilian literature took place in the nineteenth century with the emergence of romantic nationalism and social issues, including slavery. In this literature, it is essentially dualism and caricature that characterize the Black and his relationship to the White: the servile, affective and passive slave on the one hand, and the paternalistic and friendly master on the other. ${ }^{10} \mathrm{In}$ the twentieth century, literary production (including Gilberto Freyre ${ }^{11}$ ) presented the Black man as a storyteller and guardian of collective memory.

In the nineteenth century, a "multiracial" national identity discourse also emerged, whose postulate dealt with a Brazilian people based on a mixture of whites, blacks and mestizos. ${ }^{12}$ The past from which the "Black" figures are drawn is today the result of a consensus between the "dominant" (Whites) and the "dominated" (Blacks). Thus the figure of the Black is reworked from period to period, according to imaginary and social concerns.

\section{The Pretos Velhos in Umbanda}

Umbanda integrated the Pretos Velhos entities when its alleged founder Zélio de Moraes, a kardécist then visiting the macumba groups, fell in love with the Pretos Velhos, the latter being considered as good healers. ${ }^{13}$ The origin of the Preto Velho (as

9 A.C. Isaia, Les intellectuels de l'Umbanda et le nationalisme des années 1930 et 1940, "Brésil(s)" 2012, no. 1, pp. 169-189; R. Motta, L'expansion et la réinvention des religions afro-brésiliennes : réenchantement et décomposition, "Archives des Sciences sociales des Religions" 2002, no. 117, pp. 113-125.

${ }^{10}$ C.E Santos Menezes., Preto Velho: as varias faces de um presonagem religioso, Dissertação (mestrado), Universidade Estadual de Campinas, 1999, p. 19, http://repositorio.unicamp.br/jspui/handle/REPOSIP/280869 [access: 10.10.2018].

${ }^{11}$ G. Freyre, Casa Grande \& Senzala, Recife - Pernambuco - Brasil 1933, p. 728.

${ }^{12}$ However, I must qualify my point: this is not a general affirmation. Brazilian social thinking is not as homogeneous: the mixed race remains an ambiguous category where Brazilians themselves have their own representation. Nevertheless, for this article I take the position of homogenizing the discourse in order to underline the importance of this political representation in Umbanda which is, I recall, an inextricable religion of the political discourse of the time; A.C. Isaia, op. cit.

${ }_{13}$ D. Brown, Uma história da Umbanda no Rio, "Umbanda \& Política, Rio de Janeiro, ISER/Marco Zero" 1985, p. 11; M. Rougeon, Les pretos-velhos dans l'Umbanda : Un culte brésilien aux ancêtres et aux esprits d'esclaves, "Anthropologie et société" 2017, vol. 41, no. 1, pp. 281-315. 
an entity) is assumed to lie in the first magical-religious cults of slaves; it could then be a spiritual category resulting from the collective experience of slavery. ${ }^{14}$ It could also be the continuation of an ancestor cult. ${ }^{15}$ For Santos,${ }^{16}$ the presence of the Pretos Velhos in the Umbanda is to be understood both as the consequence of an African matrix of worship and as the reflection of a supposedly national culture idealized by Brazilian intellectuals.

The Pretos Velhos have been the subject of numerous studies ${ }^{17}$ through which I have been able to observe diacritical traits, invariable from one Umbanda tradition ${ }^{18}$ to another: ${ }^{19}$ they are old, exhausted, curved, humble and attentive to their "children" (filhos), a name given by these entities to visitors and mediums. These diacritical traits are tangible through four elements: songs, dances, rhythms and speeches. The songs, dances, rhythms and speeches that will provide the raw material for this article concern three Umbanda temples, one each in France, Belgium, and Switzerland. In France, the followers (mediums or members of the audience) are mostly Brazilians who have been living in France for several years. The Swiss temple is frequented by French-speaking Swiss and some Brazilians are part of the assistance ${ }^{20}$ and mediums. In Belgium, only Belgians participate in the ritual and are mediums. These temples have the specificity of being linked to a parent company located in Brazil, in the state of São Paulo. Many songs are common to three temples, but these cantos are also found in Brazilian popular culture, which itself carries many symbols related to AfroBrazilian religions. ${ }^{21}$

So the songs, their words, convey the symbols linked to the entities. These words are sung by the mediums, but also by the members of the audience. In the three temples, the audience is essentially comprised of middle-class women working in

${ }_{14}$ M. Souza, Pretos-velhos: oráculos, crença e magia entre os cariocas, Tese de Doutorado, Instituto de Filosofia e Ciências Sociais, Universidade Federal do Rio de Janeiro, Rio de Janeiro 2006, p. 117, http://livros01.livrosgratis.com.br/cp043436.pdf [access: 10.10.2018].

15 R. Nazzi, J.F.M.H. Bairrão, Aquém e além do cativeiro dos conceitos : perspectivas do preto-velho nos estudos afro-brasileiros, "Memorandum" 2011, vol. 20, p. 146.

16 C.E Santos Menezes, op. cit., p. 59.

17 M. Souza, op. cit.; idem, Escrava Anastácia e pretos-velhos: a rebelião silenciosa da memória popular, [in:] Imaginário, cotidiano e poder. Memória afro-brasileira, V.G. Da Silva (ed.), São Paulo 2007, vol. 3, pp. 15-42; C.E Santos Menezes, op. cit.; Nunes-Perreira S., É meu avô, ora! Um estudo sobre pretos-velhos no imaginário social brasileiro, Dissertação de Mestrado, Departamento de Psicologia, Pontifícia Universidade Católica, Rio de Janeiro 2006, p. 309, https://www.maxwell.vrac.pucrio.br/Busca_etds.php?strSecao=resultado\&nrSeq=8744@1 [access: 10.10.2018]; L. Hale, Preto Velho: Resistance, $\bar{R}$ edemption, and Engendered Representations of Slavery in a Brazilian Possession-Trance Religion, "American Ethnologist” 1997, vol. XXIV, p. 392-414; M. Rougeon, op. cit.

18 The specificity of Afro-Brazilian religions lies in the multiplicity of traditions. Each house (terreiro or casa) has its own tradition linked to the idiosyncrasy of the cult leader. On the invention of traditions in Afro-Brazilian religions, see S. Capone, La quête de l'Afrique dans le Candomblé, Sesto San Giovanni 2017, p. 375.

19 For an article summarizing the different researches on Pretos Velhos see: R. Nazzi, H.M.F.J. Bairrão, op. cit.

${ }^{20}$ The term assistance (or assistencia in Portuguese) refers to people who have come to participate to the ritual.

${ }^{21}$ J. Bahia, C. Vieira, op. cit. 
liberal professions. In France, the majority of the assistance are Brazilian. In Switzerland, we find a majority of Swiss natives and some Brazilians; and in Belgium, only Belgians. The members of assistance (except Brazilians) do not yet speak Portuguese (the ritual language) and sing "phonetically." ${ }^{2}$ Nevertheless, when we look at the words of these cantos, we can guess the inherent diacritical features of the entities and we can trace the invariables from one temple to another (even from one country to another since the songs come from the Brazilian temple).

I give below some examples of the pontos gathered during my fieldwork between 2014 and 2017. The following songs come from the French temple's songbook (carnet de pontos), which a medium gave to me during my ogã (musician) apprenticeship. The songs as they are in the carnet de pontos are transcribed below. I think it is important to keep this transcription because it makes tangible the importance of symbols rather than master of ritual language. When a member of the assistance wants to be a part of medium corpus, he becomes an abiã. At this moment, he starts to learn pontos with the book and without knowing, as he has not mastered Portuguese, he learns it the wrong way. Again, the most important aspect of the pontos are the symbols (which are shared through the translations, the dances, the clothes ${ }^{23}$ and in the ritual in general), not the language in itself.

Ponto no. 1

De baixo de palha tem um velho

Gerreiro e sábio, sim senhor

Tem búzios ${ }^{24}$ tem palha atoto

Atoto Obuluaié

E o velho Obuluaié, é o velho Obuluaiéé

E o velho Obuluaié, atoto Obuluaié

Under the straw is an old man

Warrior and wise, yes lord

There is the búzios there is the straw atoto

Atoto Obuluaié

And old Obuluaié, he is old Obuluaié

And old Obuluaié, atoto Obuluaié

${ }^{22}$ Some of members of the assistance told me that they can understand some worlds but the songs itself still be abstruse. The others told me that the meaning of the songs is not important, they prefer "feel the energies."

${ }^{23}$ Depending on entities.

${ }^{24}$ Búzios are small shells (cauries) used for divination (Ifá).

${ }^{25}$ Atoto Obuluaié (Atoto Obaluaie in the right term) refers to Omulu, Orisha of old age. 
Ponto no. 2

$\mathrm{O}$ vente está soprando

Sinto cheiro de Guiné ${ }^{6}$

Preto-Velho está chegando

P'ra cuidar de quem têm fé

Preto-Velho está chegando

P'ra cuidar de quem têm fé

Vem de Aruanda ${ }^{27}$

p'ra tirar demanda

Vem defender os filhos de umbanda

The wind blows

I can smell the smell of Guinea

The old black is coming

To take care of those who have faith

The old black is coming

To take care of those who have faith

He's from Aruanda

To listen to the prayers

He defends the children of the Umbanda

Ponto no. 3

Quem ée aquele velhinho que vem no caminho

Andado devagar, com ses cachimbo na boca

Puxando a fumaça e soltando pr'o ar

Ele é do cativeiro é Paí Jacinto

Ele é mirongueiro ${ }^{28}$

Who is this man on the way

Walking slowly with his pipe in his mouth

Drawing and spitting smoke into the air

He was in captivity, that's Father Jacinto.

He's a mirongueiro

In these songs, we can see several elements guiding us on the representations of the old black man: the relationship to the earth (which can also be Mother Earth, that is to say Africa), Christianity, and old age.

${ }^{26}$ Guinea is a plant, Petiveria alliacea, and it's also been refer to the African Ouest country.

27 Aruanda is the imaginary place where the entities come from.

28 This term underlines the ambiguity of the entities: they are advisors but also have the reputation of being good healers, even witches; M. Rougeon, op. cit., p. 306. 
First of all the notion of "earth" is tacitly found in the hymns of the Pretos Velhos. For these songs, we first find the straw (palha) and buizios linked to the Omolu entity, the god of disease and rot, itself linked to the earth and the great age. Then comes Aruanda, the imaginary place from where the entities located in Angola come. I must also emphasize that the Pretos Velhos are entities related to Iemanjá, the goddess of salt waters and an allegory of Mother Earth (Africa). But more widely, references to Africa can be made through group names (nagô), plants and odor (that of Guinea, Petiveria alliacea, either ojusaju in Yoruba) or other imaginary places located in Angola such as the kingdom of Sambuê. ${ }^{29}$

In the hymns dedicated to Pretos Velhos, many words are linked to Christianity: lord (senhor), prayer (demanda), faith ( $f e$ ) and father (pai). The piety can be related to the forced conversion of slaves by the Portuguese, ${ }^{30}$ and the interpenetration of African and Catholic cults that formed this palpable syncretism through songs where the names of the Orisha meet the facts of Christian language.

The term mirongueiro is of notable importance because it refers to a typical aspect of these entities: the care. As Rougeon notes, the Pretos Velhos are at the same time ancestors, slaves and healers. ${ }^{31}$ The mironga refers to magical knowledge that was practiced by Pretos Velhos, and it is also represented by an amulet. ${ }^{32}$ It is also important to emphasise the accessories related to the representations of old age: here the pipe, but some songs refer to their canes. ${ }^{33}$ It is, once again, the panoply of the romanticized old black, which finds its roots in the literature of the nineteenth century.

The symbols representing the old age of these entities are accentuated by the rhythms (toques) played during their cantos. In the Umbanda practiced at the Temple Guaracy (European temples and the mother house in Brazil) 21 rhythms are used by the ogãs. The Pretos Velhos have three toques: Opanije, Ijexa and Arrebate.

The Opanije is a rhythm inherent to Omulu (which is mentioned in some hymns), the Orisha of the great age and disease associated with the Pretos Velhos. The Opanije is a very slow rhythm, like the Orisha representing old age. ${ }^{34}$ The Ijexa is a toque of water, very slow, and not linked with a specific Orisha, it connects with an energy. ${ }^{35}$ The Ijexa is played on a $4 / 4$ bar with a regular rhythmic character on the first two beats, then taking a syncopated character on the last two beats, giving an impression

${ }^{29}$ I could further unfold the relationship among the Pretos Velhos, slavery and mythical places through songs, but for reasons of space, I limit myself in this article to superficially emphasizing this link.

${ }^{30}$ R. Bastide, Poètes et dieux - Études afro-brésiliennes, Paris 2002, pp. 183-221; M. Rougeon, op. cit.

${ }^{31}$ M. Rougeon, op. cit.

${ }^{32}$ The mirongueiro is the person who provides care; mironga refers to the magical knowledge and the amulet.

33 The pipe and the cane are also the symbols of mediumship.

${ }^{34}$ T. de Oliveira Pinto, Making Ritual Drama: Dance, Music and Representation in Brazilian "Candomblé" and "Umbanda", "The World of Music" 1991, vol. 33, no. 1, p. 78.

${ }^{35}$ Some toques are based on the idea of energy as it is thought in the Xirê (the cycle of life). In this case, "Ijexá" refers to the "nation" of the same name and its link to water. 
of slowing, similar to a triplet ${ }^{36}$ passage. Finally, it is the rhythm of the Arrebate, slow and appeased, that comes to represent the quietude of the Pretos Velhos. This toque has the characteristic of being built on a four beat measure; a more stable rhythm than the Ijexa, it does not allow polyrhythmic construction. However, the rhythm of the first three beats is based on a syncopated shift imparting an interesting rhythmic momentum: this tension created by the rhythmic shift seems to be resolved on the last beat, which seems to close the rhythm by giving it a fixed character (always in opposition to the Ijexa).

During my apprenticeship at the agôgô $\hat{o}^{37}$ in the French temple, the ogã in charge of my teaching reproached me for playing "too fast:" he stopped me, repeating: "it is necessary to play for a very old person who suffered all his life." The rhythm linked to the Pretos Velhos seems to be attached to the image of the old black conveyed by the songs: they are almost impotent, exhausted by the years, temperate, and sagacious. These Pretos Velhos characteristics will be supported by two other dimensions: entity discourse during interviews, and dance.

In religious practices such as Umbanda, the body must be understood according to the principles of ethnoscenology, as defined as the skenos (which comes from the Hippocratic lexicon): the body as it embodies the imagination in action. ${ }^{38}$ The first external signs ${ }^{39}$ of medium incorporation are first the face: rictus mark the wrinkles on the faces, then the curved back. Each medium walks slowly, helped by his assistant (cambono) or his cane, as if each step was a pain. The body is on the border between the reproduction of the Brazilian imagination (performed through these dances) and that of the group as well as the individual. If the songs, rhythms and dances are in conformity with the romanticized idea of a former slave from Brazil, when this entity transmigrates in Europe the Brazilian imagination intertwines with that of the medium, where the Pretos Velhos remains an old storyteller, but also where allusions to slavery disappear. Indeed, the diacritical traits of the Pretos Velhos presented in the songs and rhythms are reinvested in a Western imagination where the notion of "old black" is transformed into "old," preserving only the "old storyteller" aspect of this entity. Furthermore, not all entities speak the ritual language (Portuguese), but only speak French, which is considered their original language. The fact that French could be the native language of Pretos Velhos underlines another point in the adaptation process, and also the negotiation of symbols: Umbanda as an individualistic cult within mediumship is the key of a spiritual quest. ${ }^{40}$ The entity is considered as a part of the medium (like an "avatar"). In this way, it is totally logical for an entity to speak French.

${ }^{36}$ The triplet allows a binary pulse to be divided into three equal parts, giving the rhythm a feeling of slowing down.

${ }^{37}$ Double bell idiophone without casement.

${ }^{38}$ See La Scène et la terre : questions d'ethnoscénologie, [Collectif], Paris 1996, p. 284.

${ }^{39}$ Cries (ilá) are also one of the signs of incorporation, but in this article I focus mainly on the characteristics of Pretos Velhos as a whole: cries are specific to each medium (to each entity) but no specific cries related to the figure of the Preto Velho.

${ }^{40} \mathrm{~V}$. Teisenhoffer, Umbanda, New Age et psychothérapie. Aspects de l'implantation de l'umbanda à Paris, http://ateliers.revues.org/872 [access: 10.10.2018]; idem, Produire un soi spirituel - Pratiques 
However, the Preto Velho is an entity capable of adapting itself to the values of the group in which it is integrated: it is difficult not to agree, or not to find an analogy with the notions of generosity, gentleness and benevolence. If the Amerindians found their counterpart in Europe thanks to the idea of nature, the former slaves found in analogy the idea of a grandfather or a grandmother guiding future generations towards a future where everyone could be fulfilled. ${ }^{41}$

We must keep in mind that one of the adaptation strategies of African-American religions is to play on what is said and what is not said, to create ambiguous discourses. These strategic misunderstandings make it possible to establish a dialogue between the actors and the religious systems: they are an aid to prepare and to facilitate the encounter with this new religious system. Thus, "consensual signifiers" are mobilized (these signifiers are words but also images); they play the role of langage neutralise (neutralized language). ${ }^{42}$ Based on Bourdieu's concept, ${ }^{43}$ Stefania Capone uses it to underline the agreements put in place by actors or groups of actors through signifiants consensuels (consensual signifiers) like images, objects or terms, which serve to build consensus through their simplicity. But behind each signifiant consensuel, each actor puts a different meaning. The neutralized language is set up in a "trading zone" (a concept that Capone borrows from Peter Galison ${ }^{44}$ ): a transaction zone where locals coordinate between the different sub-cultures. This a space where different partners agree locally in the exchange, even if they oppose each other in the general meaning of what they exchange. ${ }^{45}$ The figure of the Preto Velho does not escape this idea of signifiant consensuel, because even if the songs are explicit about the diacritical features of this entity (the Preto Velho is old, slow, and benevolent), European practitioners remain free to integrate any form of images. In this case, we can find European old age representations close to the romantic period of the eighteenth century, themselves taken from the image of the old man of antiquity where old age is perceived as a noble thing (with grey hair as a sign of wisdom). The image of the old man sitting in his armchair surrounded by his children and grandchildren who came to listen to his teachings began to spread as early as this romantic

et expériences rituelles dans l'Umbanda du Temple Guaracy de Paris (France), $\mathrm{PhD}$ thesis, Université Paris X, Paris 2016, https://www.academia.edu/20253264/Introduction_th\%C3\%A8se_Produire_ un_soi_spirituel._Pratiques_et_exp\%C3\%A9riences_rituelles_dans_1_umbanda_du_Temple_Guaracy_ de_Paris_France_sous_la_direction_de_Michael_Houseman_soutenue_le_8 septembre_2015 [access: 10.10.2018]. One of the key points of the adaptation of Umbanda in Europe is its ability to adapt to New Age concepts (S. Capone, La diffusion des religions afro-américaines en Europe, "Psychopathologie africaines" 2001-2002, vol. 31, no. 1, pp. 3-16). New Age is characterised by its individualistic aspect, one of the most striking aspects of which can be found in the fact that entities can speak French (the medium's mother tongue).

${ }^{41}$ V. Teisenhoffer, Produire un soi spirituel..., op. cit.

${ }^{42} \mathrm{~S}$. Capone, Le pai-de-santo et le babalawo. Interaction religieuse, malentendus et réarrangements rituels au sein de la religion des orisha, [in:] La religion des orisha - Un champ social transnational en pleine recomposition, K. Argyriadis, S. Capone (éds.), Paris 2011, pp. 51-95.

${ }_{43}$ See P. Bourdieu, Langage et pouvoir symbolique, Paris 2001.

${ }^{44}$ P. Galison, op. cit., p. 982.

45 S. Capone, Le pai-de-santo..., op. cit., pp. 88-89. 
period. ${ }^{46}$ Thus, among the Pretos Velhos of Europeans, the image of the wise old storyteller supplants that of the former slave, while maintaining the register of family and the wisdom that comes with age.

\section{Conclusion}

National debates and history provide the basic materials of the Umbanda through colonization and the birth of a united Brazilian nation as a project of the republic. This imagination is preserved and reworked through possession (the archetypes), but also through songs, a true oral transmission that does not only affect those initiated into worship: pontos are inscribed in popular culture through capoeira and samba. ${ }^{47}$ Thus, the Preto Velho is a "symbol character" constructed from social representations, but it also conforms to the values of the group within which it is incorporated. Moreover, it conforms to the values and representations of the medium that embodies it (social group, sex, emotional state). Thus, as Nazzi and Bairrão, ${ }^{48}$ Souza, ${ }^{49}$ Santos Menezes, ${ }^{50}$ Nunes Pereira ${ }^{51}$ Hale, ${ }^{52}$ and Rougeon ${ }^{53}$ point out, the Preto Velho cannot be understood solely in a global way, that is, as part of an immutable pantheon. It is necessary to pay attention to the particularities of each Umbanda's tradition, because the specificity of the African-American religions lies in their phagocytic and flexible dynamics: ${ }^{54}$ they are what Csordas calls "portable practices." 55 These practices are capable of being restituted, "indigenized" (to use Appadurai's term) and must therefore be thought of as "local." Moreover, the importance of music in the integration of these entities into the European imagination should not be overlooked: the dances and rhythms allow Europeans followers to invest these entities in the prism of their own conceptions of the "old."

46 P. Ariès, Une histoire de la vieillesse?, "Communications" 1983, no. 37, Le continent gris. Vieillesse et vieillissement, Sous la direction de Nicole Benoit-Lapierre, pp. 48-49.

${ }^{47}$ M. Guimarães Moreira, C. Mestranda, Metáforas da Memória e da Resistência: uma analise dos pontos cantados na Umbanda, http:/www.abralic.org.br/eventos/cong2008/AnaisOnline/simposios/ pdf/024/CARINA_MOREIRA.pdf [access: 10.10.2018]; J. Bahia, C. Vieira, op. cit.

48 R. Nazzi, J.F.M.H. Bairrão, op. cit., pp. 154.

${ }^{49}$ M. Souza, Escrava Anastácia e pretos-velhos : a rebelião silenciosa da memória popular, [in:] Imaginário, cotidiano e poder: memória afro-brasileira, V.G. Silva (ed.), São Paulo 2007, vol. 3, p. 25.

50 C.E Santos Menezes, op. cit.

51 S. Nunes-Perreira, op. cit.

52 L. Hale, op. cit.

53 M. Rougeon, op. cit.

${ }^{54}$ On the transnationalization of African-American cults and adaptation strategies see also K. Argyriadis, S. Capone, R. de la Torre, A. Mary, Religions transnationales des suds - Afrique, Europe, Amériques, Paris 2011, p. 255.

55 T. Csordas, Transnational Transcendance - Essays on Religion and Globalization, San Diego 2009, p. 338.

56 La religion des orisha..., op. cit. 
Stefania Capone was one of the first researchers to work on the transnationalization of Afro-Brazilian cults in Europe (with Argyriadis, ${ }^{57}$ Pordeus $\mathrm{Jr}^{58}$ Saraiva, ${ }^{59}$ Guillot, ${ }^{60}$ Halloy, ${ }^{61}$ Teisenhoffer, ${ }^{62}$ and Rossbach de Olmos ${ }^{63}$ ). In her article, Capone notes that the religious heritage of these cults is no longer exclusively reserved for Afro-descendants. Moreover, in this same article, she details two key stages in the emergence of these religions in Europe: the search for a "true religion" on the part of Europeans and the reinterpretation of different concepts through the prism of the New Age, notably notions of "nature" which become closer to ecology discourse (as well as its sacralization ${ }^{64}$ ) and axê which is closer to holistic representation of "cosmic energy" in New Age. ${ }^{65}$

All of this can translate to the Afro-Brazilian universe, as this is one of the adaptation mechanisms. ${ }^{66}$ Music coupled with the possibility of investing entities with a European imagination can be understood as a "religious hybridization," 67 meaning a "resymbolization process in which the memory of objects is preserved and in which the tension between disparate elements generates new cultural objects which correspond to attempts to translate or subversively inscribe the original culture into a new culture." Thus, the Preto Velho is no longer linked to his slave past but is essentially

${ }^{57}$ K. Argyriadis, op. cit; La religion des orisha..., op. cit.

58 I. Pordeus Jr., Portugal em transe - Transnacionalização das religiões afro-brasileiras : conversão e performance, Lisboa 2009, p. 168.

59 C. Saraiva, Afro-Brazilian religions in Portugal: bruxos, priests and pais de santo, "Etnográfica" 2010, vol. 14, no. 2, pp. 265-288.

${ }^{60}$ M. Guillot, Du mythe de l'unité luso-afro-brésilienne, le candomblé et l'Umbanda au Portugal, "Lusotopie" 2009, vol. 16, no. 2, pp. 205-219; idem, Axé Ilê Portugal : parcours migratoires et religions afro-brésiliennes au Portugal, "Autrepart, revue de sciences sociales au sud" 2010, no. 56, pp. 57-74; idem, Logiques transnationales et stratégies locales, les étapes de l'implantation des religions afro-brésiliennes au Portugal, "Canadian Journal of African Studies/La Revue canadienne des études africaines” 2012, vol. 46, no. 3, pp. 381-395.

${ }^{61}$ A. Halloy, Un candomblé en Belgique - Traces ethnographiques d'une tentative d'installation et ses difficultés, "Psychologie Africaine" 2001-2002, vol. 31, no. 1, pp. 93-125.

${ }^{62}$ V. Teisenhoffer, Umbanda..., op. cit.; S. Capone, V. Teisenhoffer, Devenir médium à Paris : apprentissage et adaptation rituel dans l'implantation d'un terreiro de candomblé en France, "Psychopathologie africaine, Hôpital de Dakar" 2001, vol. 31, no. 1, pp. 127-156.

63 L. Rossbach de Olmos, op. cit.

${ }^{64}$ This part of Afro-Brazilian cult in Europe, precisely in German speaking Europe, was underline by Joana Bahia (Candomblé em terras alemãs, "Londrina" 2016, vol. 12, no. 18, pp. 86-104). For analyse this ecological aspect of this cult modality and its origin within the adaptation processus, she brows Manuel Castell's concept "the greening of the self" (see M. Castells, The Greening of the Self: The Environmental Movement, [in:] idem, The Power of Identity, Malden, MA 1999, pp. 113-133). Indeed, the ecological sensibilities of Swiss and German (the green identity) and the form of sacralization of the nature in Umbanda, seems to be a cross point that allowed the introduction and the practice of Umbanda in this country.

65 S. Capone, La diffusion des religions..., op. cit., p. 10; S. Capone, V. Teisenhoffer, op. cit.

66 S. Capone, La diffusion des religions..., op. cit.; idem, Le pai-de-santo et le babalawo..., op. cit.

${ }^{67}$ J. Ferreira Dias, Em Roma sê Romano - O candomblé como adaptação criativa e hibridismo, nas origens e no sec. XXI; Bahia, Lisboa e Berlim, "Revista Lusófonia de Ciência das Religiões" 2013 , vol. 10, no. 18-19, p. 205-216, quotes Z. Bernd, O elogio da crioulidade: o conceito de hibridação a partir dos autores francófonos do Caribe, [in:] Margens da cultura: mestiçagem, hibridismo e outras musituras, B. Abdala Jr. (éd.), São Paulo 2004, pp. 99-111. 
marked by his age and his experience, the entity becomes the paragon of the "old storyteller," wise and knowing many things about care for others. It is at this level that the "cultural translation" 68 takes place: if the words of the songs are explicitly turned towards references to slavery and Africa, in Europe references to old age and providing care remain the elements put forward by the mediums.

In their studies Argyriadis, ${ }^{69}$ Rossbach de Olmos, ${ }^{70}{\text { Bahia },{ }^{71} \text { and Bahia and Vieira }}^{72}$ stress the importance of aesthetics and music in the integration of Europeans into Orisha cults. Here, I wanted to underline the possibility, through music, to make the imagination migrate from one country to another and to reinvest it, by withdrawing the national or even historical aspects and by feeding common traits capable of being understood in each country where worship is established (the idea of an old person endowed with wisdom due to his age and his experiences, also a healer). In this sense it seemed relevant to me to focus, in order to understand the transnationalization of Umbanda in Europe, on the transnationalization of this entity, synthetical of the Brazilian imagination and at the same time of the capacity of being invested by other imaginaries thanks to a "working misunderstanding." This is also the work of imagination, meaning the ability of a symbol to be transcended by another and to emerge in language. It is the "semantic shock" generated by the meeting of the two meanings that will allow the construction of a new level of meaning. ${ }^{73}$ Thus, the symbol of the former black slave, which is discovered tacitly through the songs, meets the symbol of the "old," European stereotypes linked to old age,$^{74}$ giving a new symbol that will be linked to the name of the Preto Velho but which, in the end, will be linked more to the European figure of the "grandfather." This work of imagination, tangible through the speeches, makes it possible to grasp one of the central points of the adaptation of Umbanda: "no action without imagination." 75

\section{References}

Appadurai A., Après le colonialisme - Les conséquences culturelles de la globalisation, Paris 2015. Argyriadis K., Les parisiens et la santería - de l'attraction esthétique à l'implication religieuse, "Psychopathologie africaine" 2002, vol. 31, no. 1, pp. 17-44.

Argyriadis K., Capone S., Torre R. de la, Mary A., Religions transnationales des suds - Afrique,

Europe, Amériques, Paris 2011.

68 A. Frigerio, L'Umbanda et le batuque dans le Cône Sud : du flux religieux transfrontalier au champ social transnational, [in:] La religion des orisha..., op. cit., pp. 275-322.

${ }^{69}$ K. Argyriadis, op. cit.

70 L. Rossbach de Olmos, op. cit.

71 J. Bahia, Dancing with the Orixás. Music, Body and the Circulation of African Candomblé Symbols in Germany, "African Diaspora" 2016, no. 9, pp. 15-38.

72 J. Bahia, C. Vieira, op. cit.

73 P. Ricoeur, Du texte à l'action : essais d'herméneutique, Paris - Seuil 1986.

74 P. Ariès, op. cit.

75 P. Ricoeur, op. cit., p. 213. 
Ariès P., Une histoire de la vieillesse?, "Communications” 1983, no. 37, Le continent gris. Vieillesse et vieillissement, Sous la direction de Nicole Benoit-Lapierre, pp. 47-54.

Bahia J., Candomblé em terras alemãs, "Londrina" 2016, vol. 12, no. 18, pp. 86-104.

Bahia J., Dancing with the Orixás. Music, Body and the Circulation of African Candomblé Symbols in Germany, "African Diaspora” 2016, no. 9, pp. 15-38.

Bahia J., Religiosidad afro-brasileño en Berlín : adaptaciones en la transnacionalización del candomblé, "Sociedad y discurso" 2005, no. 28(7), pp. 7-25.

Bahia J., Under the Berlin Sky. Candomble on German shores, "Vibrant" 2014, vol. 11, no. 2, pp. 327-370.

Bahia J., Vieira C., Performances artísticas e circularidades das simbologias afro religiosas, "Revista brasileira de História das Religiões" 2017, vol. 9, no. 17, pp. 171-188.

Bastide R., Les religions africaines au Brésil - Contribution à une sociologie des interpénétrations de civilisation, Paris 1995.

Bastide R., Poètes et dieux - Études afro-brésiliennes, Paris 2002.

Bernd Z., O elogio da crioulidade: o conceito de hibridação a partir dos autores francófonos do Caribe, [in:] Margens da cultura: mestiçagem, hibridismo e outras musituras, B. Abdala Jr. (éd.), São Paulo 2004, pp. 99-111.

Bourdieu P., Langage et pouvoir symbolique, Paris 2001.

Brown D., Uma história da Umbanda no Rio, "Umbanda \& Política, Rio de Janeiro, ISER/Marco Zero" 1985, pp. 9-42

Capone S., La diffusion des religions afro-américaines en Europe, "Psychopathologie africaines" 2001-2002, vol. 31, no. 1, pp. 3-16.

Capone S., La quête de l'Afrique dans le Candomblé, Sesto San Giovanni 2017.

Capone $\mathrm{S}$., Le pai-de-santo et le babalawo. Interaction religieuse, malentendus et réarrangements rituels au sein de la religion des orisha, [in:] La religion des orisha - Un champ social transnational en pleine recomposition, K. Argyriadis, S. Capone (éds.), Paris 2011, pp. 51-95.

Capone S., Teisenhoffer V., Devenir médium à Paris : apprentissage et adaptation rituel dans l'implantation d'un terreiro de candomblé en France, "Psychopathologie africaine, Hôpital de Dakar" 2001, vol. 31, no. 1, pp. 127-156.

Castells M., The Greening of the Self: The Environmental Movement, [in:] idem, The Power of Identity, Malden, MA 1999, pp. 113-133.

Csordas T., Transnational Transcendance - Essays on Religion and Globalization, San Diego 2009.

Ferreira Dias J., Em Roma sê Romano - O candomblé como adaptação criativa e hibridismo, nas origens e no sec. XXI; Bahia, Lisboa e Berlim, "Revista Lusófonia de Ciência das Religiões" 2013, vol. 10, no. 18-19, pp. 205-216.

Freyre G., Casa Grande \& Senzala, Recife - Pernambuco - Brasil 1933.

Frigerio A., L'Umbanda et le batuque dans le Cône Sud : du flux religieux transfrontalier au champ social transnational, [in:] La religion des orisha - Un champ social transnational en pleine recomposition, K. Argyriadis, S. Capone (éds.), Paris 2011, pp. 275-322.

Galison P., Image and Logic. A Material Culture of Microphysics, Chicago 1997.

Guillot M., Axé Ilê Portugal : parcours migratoires et religions afro-brésiliennes au Portugal, "Autrepart, revue de sciences sociales au sud" 2010, no. 56, pp. 57-74.

Guillot M., Du mythe de l'unité luso-afro-brésilienne, le candomblé et l'Umbanda au Portugal, "Lusotopie" 2009, vol. 16, no. 2, pp. 205-219.

Guillot M., Logiques transnationales et stratégies locales, les étapes de l'implantation des religions afro-brésiliennes au Portugal, "Canadian Journal of African Studies/La Revue canadienne des études africaines” 2012, vol. 46, no. 3, pp. 381-395.

Guimarães Moreira M., Mestranda C., Metáforas da Memória e da Resistência : uma analise dos pontos cantados na Umbanda, http://www.abralic.org.br/eventos/cong2008/AnaisOnline/simposios/pdf/024/CARINA_MOREIRA.pdf [access: 10.10.2018]. 
Hale L., Preto Velho: Resistance, Redemption, and Engendered Representations of Slavery in a Brazilian Possession-Trance Religion, "American Ethnologist” 1997, vol. XXIV, pp. 392-414.

Halloy A., Un candomblé en Belgique - Traces ethnographiques d'une tentative d'installation et ses difficultés, "Psychologie Africaine" 2001-2002, vol. 31, no. 1, pp. 93-125.

Isaia A.C., Les intellectuels de l'Umbanda et le nationalisme des années 1930 et 1940, "Brésil(s)" 2012, no. 1, pp. 169-189.

La religion des orisha - Un champ social transnational en pleine recomposition, K. Argyriadis, S. Capone (éds.), Paris 2011.

La Scène et la terre : questions d'ethnoscénologie, [Collectif], Paris 1996.

Megenney W., Rasgos neo-africanos en algunos cánticos brasileños de los Pretos Velhos (Umbanda), "Anuario de lingüística hispánica" 2003, pp. 11-40.

Motta R., L'expansion et la réinvention des religions afro-brésiliennes : réenchantement et décomposition, "Archives des Sciences sociales des Religions" 2002, no. 117, pp. 113-125.

Nazzi R., Bairrão J.F.M.H., Aquém e além do cativeiro dos conceitos : perspectivas do preto-velho nos estudos afro-brasileiros, "Memorandum" 2011, vol. 20, pp. 145-176.

Negrão L.N., Umbanda: entre a cruz e a encruzilhada, "Tempo Social" 1993, vol. 5 no. 1-2, pp. 113-122.

Nunes-Perreira S.E, É meu avô, ora! Um estudo sobre pretos-velhos no imaginário social brasileiro, Dissertação de Mestrado, Departamento de Psicologia, Pontifícia Universidade Católica, Rio de Janeiro 2006, https://www.maxwell.vrac.puc-rio.br/Busca_etds.php?strSecao=resultad o\&nrSeq=8744@1 [access: 10.10.2018].

Oliveira Pinto T. de, Making Ritual Drama: Dance, Music and Representation in Brazilian "Candomblé" and "Umbanda", "The World of Music" 1991, vol. 33, no. 1, pp. 70-88.

Pordeus I. Jr., Portugal em transe - Transnacionalização das religiões afro-brasileiras : conversão e performance, Lisboa 2009.

Ricoeur P., Du texte à l'action : essais d'herméneutique, Paris - Seuil 1986.

Rougeon M., Les pretos-velhos dans l'Umbanda : Un culte brésilien aux ancêtres et aux esprits d'esclaves, "Anthropologie et société" 2017, vol. 41, no. 1, pp. 281-315.

Rossbach de Olmos L., Santeria Abroad. The Short History of an Afro-Cuban Religion in Germany by Means of Biographies of Some of Its Priests, "Anthropos” 2009, vol. 104, pp. 483-497.

Santos Menezes C.E., Preto Velho: as varias faces de um presonagem religioso, Dissertação (mestrado), Universidade Estadual de Campinas, 1999, http://repositorio.unicamp.br/jspui/handle/ REPOSIP/280869 [access: 10.10.2018].

Saraiva C., Afro-Brazilian religions in Portugal: bruxos, priests and pais de santo, "Etnográfica" 2010, vol. 14, no. 2, pp. 265-288.

Souza M., Escrava Anastácia e pretos-velhos : a rebelião silenciosa da memória popular, [in:] Imaginário, cotidiano e poder: memória afro-brasileira, V.G. Silva (ed.), São Paulo 2007, vol. 3, pp. 15-42.

Souza M., Pretos-velhos: oráculos, crença e magia entre os cariocas, Tese de Doutorado, Instituto de Filosofia e Ciências Sociais, Universidade Federal do Rio de Janeiro, Rio de Janeiro 2006, http://livros01.livrosgratis.com.br/cp043436.pdf [access: 10.10.2018].

Teisenhoffer V., Produire un soi spiritual - Pratiques et expériences rituelles dans l'Umbanda du Temple Guaracy de Paris (France), PhD thesis, Université Paris X, Paris 2016, https:// www.academia.edu/20253264/Introduction_th\%C3\%A8se_Produire_un_soi_spirituel._Pratiques_et_exp\%C3\%A9riences_rituelles_dans_1_umbanda_du_Temple_Guaracy_de_Paris_ France_sous_la_direction_de_Michael_Houseman_soutenue_le_8_septembre_2015 [access: 10.10.2018].

Teisenhoffer V., Umbanda, New Age et psychothérapie. Aspects de l'implantation de l'umbanda à Paris, http://ateliers.revues.org/872 [access: 10.10.2018]. 